\title{
PERUBAHAN MUTU DAN UMUR SIMPAN SUP DAUN TORBANGUN (Colues amboinicus Lour) DALAM KEMASAN
}

\author{
(Quality and shelf life of packaged torbangun leaves soup)
}

\author{
Endang Warsiki ${ }^{1}$ dan M. Rizal M. Damanik ${ }^{2 *}$ \\ 1'Departemen Teknologi Industri Pertanian, Fakultas Teknologi Pertanian (FATETA), Institut Pertanian Bogor. \\ Jl. Raya Darmaga, Bogor 16880 \\ ${ }^{2}$ Departemen Gizi Masyarakat, Fakultas Ekologi Manusia (FEMA), Institut Pertanian Bogor, \\ Jl. Raya Darmaga, Bogor 16880
}

\begin{abstract}
Torbangun leaves soup is one of the traditional diets commonly consumed by lactating mothers among the Batak society. The soup is believed to increase breast milk production and helps recovery process after the mother giving birth. Unfortunately, until now the soup is only served directly after cooking thereby limits its usefulness. Given the potential of the soup is quite important, the preservation of the cooked soup needs to be done so that the soup can be consumed at anytimeany time. This study aims to determine the shelf life of torbangun soup in a variety of packaging and at various storage temperatures. The soup is stored at three different temperatures $\left(3-5^{\circ} \mathrm{C}, 10-12^{\circ} \mathrm{C}\right.$ and $\left.27-30^{\circ} \mathrm{C}\right)$ and in 3 types of packaging namely polyethylene terephthalate (PET), polypropylene (PP) and cans. Changes in product quality during storage are analyzed and estimated the shelf life of products. The results show that the soup stored at the $3-5^{\circ} \mathrm{C}$ and $10-12^{\circ} \mathrm{C}$ has longer shelf life compared to $27-30^{\circ} \mathrm{C}$ (day 8 vs day 3). In addition, the cans are the best packing among other packaging materials.
\end{abstract}

Key words: torbangun leaf, Coleus amboinicus Lour, soup, shelf life

\begin{abstract}
ABSTRAK
Sup daun Torbangun torbangun adalah salah satu makanan tradisional yang biasa dikonsumsi oleh ibu menyusui di kalangan masyarakat Batak. Sup ini diyakini dapat meningkatkan produksi ASI dan membantu proses pemulihan setelah ibu melahirkan. Sayangnya, sampai saat ini sup daun torbangun hanya disajikan langsung setelah dimasak sehingga membatasi kegunaannya. Mengingat potensi sup ini cukup penting, penggunaan bahan pengawet pada sup matang perlu dilakukan agar sup ini dapat dikonsumsi kapan saja. Penelitian ini bertujuan untuk menentukan umur simpan sup torbangun dalam berbagai kemasan dan pada berbagai suhu penyimpanan. Pada penelitian ini sup disimpan pada tiga suhu berbeda $\left(3-5^{\circ} \mathrm{C}, 10-12^{\circ} \mathrm{C}\right.$ dan $\left.27-30^{\circ} \mathrm{C}\right)$ dan di simpan dalam tiga jenis kemasan yaitu polietilen tereftalat (PET), polypropylene (PP) dan kaleng. Perubahan kualitas produk selama penyimpanan dianalisis dan dilakukan perkiraan umur simpan produk. Hasil penelitian menunjukkan bahwa sup yang disimpan pada suhu $3-5^{\circ} \mathrm{C}$ dan $10-12^{\circ} \mathrm{C}$ memiliki umur simpan lebih lama dibandingkan dengan sup yang disimpan pada suhu $27-30^{\circ} \mathrm{C}$ ( 8 hari vs 3 hari). Selain itu kaleng adalah kemasan terbaik di antara bahan kemasan lainnya.
\end{abstract}

Kata kunci: daun torbangun, Coleus amboinicus Lour, sup, umur simpan

"Korespondensi: Departemen Gizi Masyarakat, Fakultas Ekologi Manusia (FEMA), Institut Pertanian Bogor, Tel: 0251 - 8621363; Email: damanik31@yahoo.com 


\section{PENDAHULUAN}

Sup daun torbangun merupakan salah satu makanan khas di daerah Batak untuk ibu menyusui. Sup daun torbangun dipercaya dapat meningkatkan produksi air susu ibu (Santosa 2001; Damanik et al. 2001; Damanik et al. 2004). Hal tersebut diperkuat oleh hasil penelitian Damanik (2005) dan Damanik et al. (2006) yang menyatakan bahwa konsumsi sayur daun torbangun pada ibu menyusui dapat meningkatkan volume ASI dan kandungan beberapa mineral seperti zat besi, kalium, seng dan magnesium serta mengakibatkan peningkatan berat badan bayi secara nyata.

Sup daun torbangun merupakan sup bersantan dengan bumbu-bumbu penambah cita rasa ( $\mathrm{Da}$ manik et al. 2006). Konsistensi sup yang kental dengan lemak dan protein yang tinggi, menyebabkan sup torbangun mudah rusak. Upaya menunda kerusakan merupakan hal yang penting dalam meningkatkan nilai tambah bagi produk sup daun torbangun. Usaha ini perlu pengetahuan: (i) cara pengolahan sup yang benar agar tidak berkurang nilai gizinya dan (ii) cara pengemasan dan suhu penyimpanan yang tepat agar mempunyai umur simpan lama (Damayanthi et al. 2008; Warsiki et al. 2009). Penentuan umur simpan sup daun torbangun menjadi kajian penting untuk usaha komersialisasi produk ini. Lebih lanjut, umur simpan suatu produk sangat erat kaitannya dengan perubahan mutu produk. Penelitian ini bertujuan untuk mengetahui perubahan mutu sup daun torbangun dalan kemasan dan mendapatkan jenis kemasan dan kondisi penyimpanan yang memberikan umur simpan sup terlama dengan mutu terbaik.

\section{METODE}

Penelitian ini dilakukan dalam dua tahap, yaitu penelitian pendahuluan dan penelitian utama. Pada penelitian pendahuluan dilakukan pengamatan visual untuk mengetahui lamanya waktu sup daun torbangun (dalam kemasan) mengalami kerusakan pada suhu yang diujikan. Penelitian utama dilakukan dengan menggunakan Rancangan Acak Lengkap Faktorial tiga faktor dengan dua kali ulangan. Faktor perlakuan A adalah jenis kemasan, yaitu kemasan plastik PET (A1), PP (A2), dan kaleng (A3), faktor $B$ adalah suhu penyimpanan, yaitu suhu $3-5^{\circ} \mathrm{C}$ (B1), $10-12^{\circ} \mathrm{C}$ (B2) dan suhu $27-30^{\circ} \mathrm{C}$ (B3), serta faktor C adalah lama penyimpanan yaitu hari ke-1 hingga hari di mana produk dinyatakan rusak. Pengamatan pada penelitian utama dilakukan terhadap analisis $\mathrm{pH}, \mathrm{TPC}$ (total plate count), total asam tertitrasi, thiobarbituric acid (TBA).

\section{Bahan dan Alat}

Bahan baku utama yang digunakan dalam penelitian ini adalah daun torbangun serta bumbu- bumbu untuk membuat sup daun torbangun. Bahan kemasan yang digunakan adalah kemasan plastik polietilen tereftalat (PET), kemasan plastik polipropilene (PP) serta kemasan kaleng. Adapun bahan yang digunakan untuk analisis kimia dan mikrobiologi antara lain thiosulfat 0,1 N, HCl $4 \mathrm{M}$, PCA (Plate Count Agar), indikator phenolphthalein, asam asetat glasial, kloroform, dan KI jenuh. Alat-alat yang digunakan dalam penelitian antara lain neraca, refrigerator, labu kjedahl, tanur, labu destilasi, pH meter, blender, autoklaf, tabung ulir, cawan petri, pipet volumetrik, pipet mikron, serta inkubator.

\section{HASIL DAN PEMBAHASAN}

\section{Penelitian Pendahuluan}

Dari hasil penelitian pendahuluan yang dilakukan pengamatan visual, didapatkan hasil bahwa sup daun torbangun yang disimpan pada suhu $3-5^{\circ} \mathrm{C}$ serta $10-12^{\circ} \mathrm{C}$ mengalami kerusakan pada hari ke-8, sedangkan sup daun torbangun yang disimpan pada suhu $27-30^{\circ} \mathrm{C}$ sudah mengalami kerusakan pada hari ke-3.

\section{Penelitian Utama Nilai $\mathrm{pH}$}

Derajat keasaman $(\mathrm{pH})$ sup daun torbangun mengalami penurunan selama penyimpanan. Penurunan nilai $\mathrm{pH}$ yang terjadi menunjukkan terjadinya peningkatan keasaman produk dengan makin banyaknya jumlah mikroba penghasil asam organik yang tumbuh pada sup daun torbangun seiring lama waktu penyimpanan. Hasil pengukuran pH disajikan pada Gambar 1.

Hasil sidik ragam pada analisis $\mathrm{pH}$ menunjukkan bahwa faktor suhu, kemasan, dan hari serta interaksi di antara ketiganya memperlihatkan pengaruh yang nyata. Selanjutnya, hasil penelitian memperlihatkan bahwa kemasan kaleng suhu $3-5^{\circ} \mathrm{C}$ sebagai kemasan dan suhu terbaik untuk pengujian nilai $\mathrm{pH}$. Hal ini disebabkan pada suhu $3-5^{\circ} \mathrm{C}$, aktivitas mikroba melambat. Selain itu, kemasan kaleng mampu menahan laju reaksi pertukaran gas maupun uap air antara bahan pangan dengan lingkungan yang lebih baik dibandingkan kemasan plastik PET dan PP sehingga mampu menahan laju peningkatan pembentukan asam organik oleh mikroba penghasil asam.

\section{Total asam tertitrasi (TAT)}

Nilai total asam tertitrasi (TAT) dalam penelitian ini digunakan sebagai salah satu parameter untuk menentukan mutu sup daun torbangun. Hasil analisis TAT menunjukkan bahwa bilangan TAT sup daun torbangun memiliki nilai kisaran 2.3925 hingga $4.81405 \mathrm{ml} \mathrm{NaOH} 0.1 \mathrm{~N} / 100$ gram. Selama penyimpanan, sup daun torbangun menunjukkan peningkatan nilai TAT. Hal ini berarti keasaman produk sup 
daun torbangun mengalami peningkatan seiring lamanya penyimpanan. Hasil sidik ragam pada analisis TAT menunjukkan bahwa faktor suhu, kemasan, dan hari memperlihatkan pengaruh yang nyata.

Hasil penelitian menunjukkan bahwa kombinasi kaleng dan suhu $3-5^{\circ} \mathrm{C}$ (A3B1) merupakan kombinasi terbaik bagi pengujian nilai TAT. Hal ini disebabkan pada suhu $3-5^{\circ} \mathrm{C}$, aktivitas mikroba melambat akibat aktivitas enzim yang terhambat serta dikarenakan kemasan kaleng yang mampu menahan laju reaksi pertukaran gas maupun uap air antara bahan pangan dengan lingkungan yang lebih baik dibandingkan kemasan plastik PET dan PP sehingga mampu menahan laju peningkatan pembentukan asam organik oleh mikroba penghasil asam.

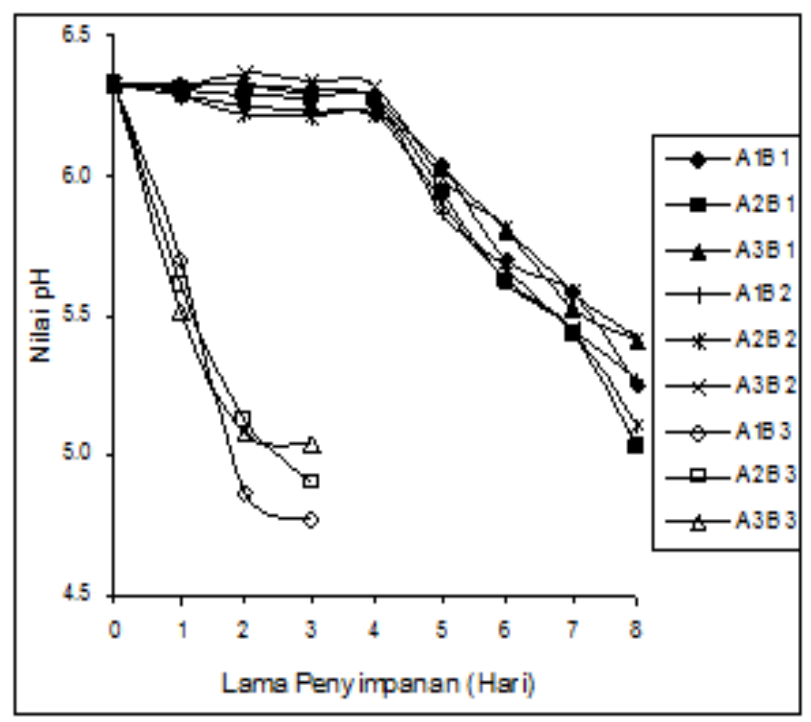

Gambar 1. Grafik pH Sup Daun Torbangun selama Penyimpanan

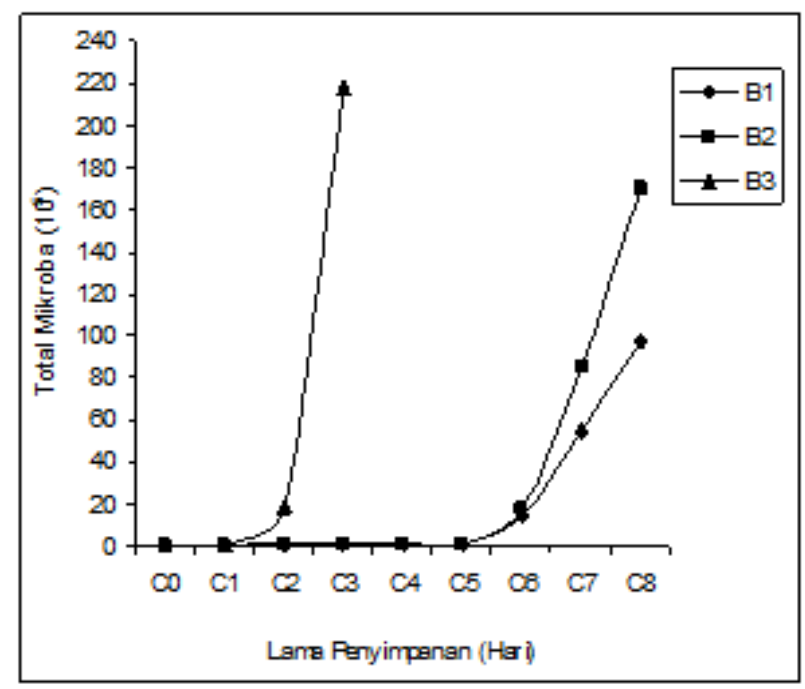

Gambar 3. Interaksi Suhu dan Lama Penyimpanan terhadap Total Mikroba Sup Daun Torbangun

\section{Total Plate Count (TPC)}

Hasil analisis nilai TPC menunjukkan bahwa jumlah mikroba sup daun torbangun memiliki nilai kisaran $30 \times 102-234 \times 105$ koloni/gram. Hal tersebut dapat dilihat pada Gambar 2. Selama penyimpanan, sup daun torbangun menunjukkan peningkatan nilai TPC. Hal ini berarti total mikroba produk sup daun torbangun mengalami peningkatan seiring lamanya penyimpanan. Hasil sidik ragam pada analisis TPC menunjukkan bahwa faktor suhu, kemasan, dan hari memperlihatkan pengaruh yang nyata (Gambar 3 dan 4).

Hasil penelitian memperlihatkan bahwa kombinasi kaleng dan suhu $3-5^{\circ} \mathrm{C}$ merupakan kombinasi terbaik bagi pengujian nilai TPC. Hasil yang sama,

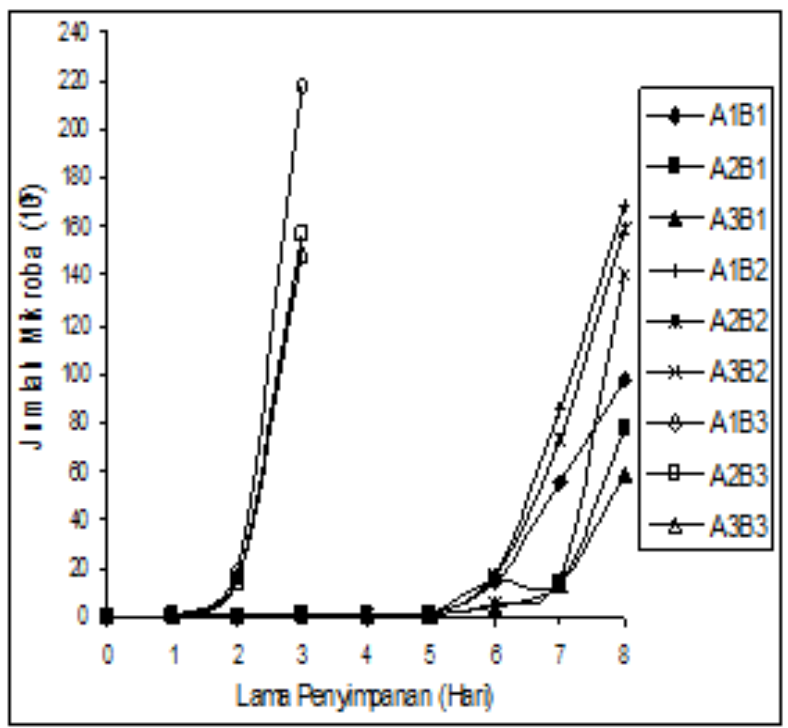

Gambar 2. Total Mikroba Sup Daun Torbangun selama Penyimpanan

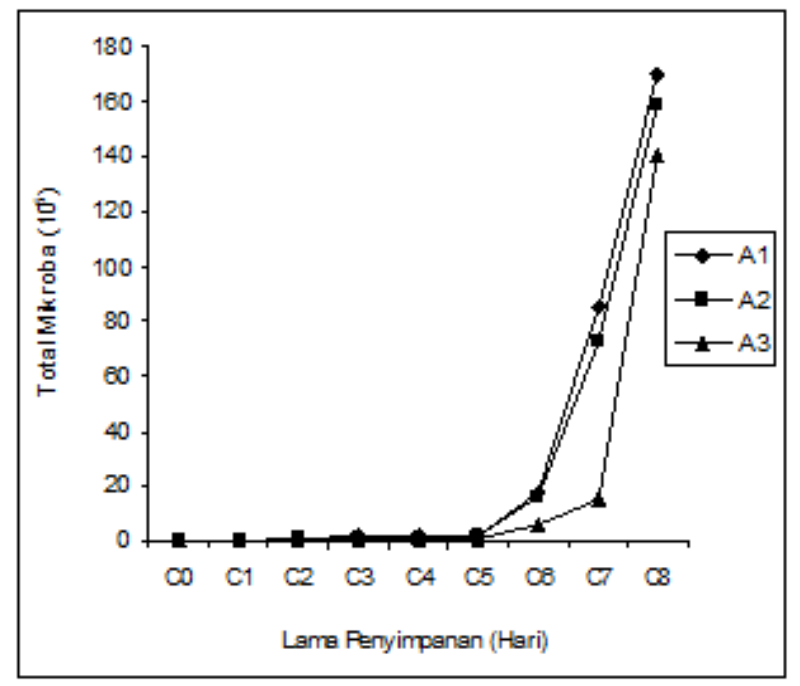

Gambar 4. Interaksi Kemasan dan Hari terhadap Total Mikroba Sup Daun Torbangun 
walaupun berbeda suhu penyimpanan, juga disampaikan oleh Warsiki et al. (2009).

Sup daun torbangun dalam kemasan yang disimpan pada suhu dingin $\left(3-5^{\circ} \mathrm{C}\right)$ terlihat lebih lambat peningkatan jumlah mikrobanya dikarenakan suhu simpan yang rendah mempengaruhi aktivitas enzim yang mengkatalisasi reaksi-reaksi biokimia dalam sel mikroorganisme.

Sup daun torbangun yang dikemas dengan kaleng menunjukkan hasil paling rendah peningkatan jumlah mikroba per harinya. Hal tersebut menunjukkan bahwa kemasan kaleng merupakan kemasan yang paling efektif sebagai pelindung produk terhadap masuknya mikroba dibandingkan kemasan plastik PET dan PP.

\section{Thiobarbituric Acid (TBA)}

Bilangan TBA merupakan petunjuk terjadinya degradasi sekunder terhadap senyawa lemak yang membentuk senyawa aldehida. Hasil analisis bilangan TBA menunjukkan bahwa bilangan TBA sup daun torbangun memiliki nilai kisaran 0.2487-0.4865 mg malonaldehida/kg sampel. Selama penyimpanan, sup daun torbangun menunjukkan peningkatan bilangan TBA. Hal tersebut menunjukkan bahwa peningkatan bilangan TBA disebabkan adanya ketengikan yang terjadi karena perubahan komposisi lemak, selanjutnya mengalami oksidasi menghasilkan peroksida, keton, dan aldehida.

Hasil sidik ragam pada analisis TBA menunjukkan bahwa faktor suhu dan hari memperlihatkan pengaruh yang nyata. Berdasarkan hasil penelitian, terlihat bahwa perlakuan terbaik dicapai oleh kemasan kaleng pada suhu $3-5^{\circ} \mathrm{C}$ yang pada hari ke-8 masih menunjukkan peningkatan bilangan TBA yang cukup rendah di antara kemasan lainnya. Hal tersebut menunjukkan bahwa kemasan kaleng merupakan kemasan yang paling efektif sebagai pelindung produk terhadap masuknya udara, gas, dan mikroba.

Sup daun torbangun yang disimpan pada suhu 3-5 ${ }^{\circ} \mathrm{C}$ terlihat menunjukkan peningkatan bilangan TBA yang cenderung lambat. Hal ini dikarenakan suhu $3-5^{\circ} \mathrm{C}$ yang merupakan penyimpanan suhu dingin menyebabkan proses oksidasi melambat sehingga terbentuknya aldehid dan malonaldehida penyebab ketengikan menjadi sedikit terhambat.

\section{KESIMPULAN}

Berdasarkan hasil pengamatan visual saat penelitian pendahuluan diketahui bahwa sup daun torbangun yang disimpan pada suhu $3-5^{\circ} \mathrm{C}$ serta 10 $12^{\circ} \mathrm{C}$ mengalami kerusakan pada hari ke-8, sedangkan sup daun torbangun yang disimpan pada suhu 27-30 ${ }^{\circ} \mathrm{C}$ sudah mengalami kerusakan pada hari ke3. Selama penyimpanan, nilai pH mengalami penurunan yang berarti juga mengalami peningkatan nilai total asam tertitrasi. Selain itu nilai total mikroba dan thiobarbituric acid pun cenderung mengalami peningkatan. Berdasarkan hasil analisis, kemasan kaleng yang disimpan pada suhu dingin $3-5^{\circ} \mathrm{C}$ memberikan hasil terbaik.

\section{DAFTAR PUSTAKA}

Damanik R, Damanik N, Daulay Z, Saragih S, Premier $\mathrm{R}$, Wattanapenpaiboon N \& ML. Wahlqvist. 2001. Consumption of bangun-bangun leaves (Coleus amboinicus Lour) to increase breast milk production among bataknese women in North Sumatera Island, Indonesia. Asia Pacific Journal of Clinical Nutrition, 10(4), S67

Damanik R, Watanapenpaiboon N \& Wahlqvist ML. 2004. The use of a putative lactagogue plant on breast milk production in Simalungun, North Sumatra, Indonesia. Asia Pacific Journal of Clinical Nutrition, 16(4), S87

Damanik R. 2005. Fatty acid intake of the bataknese lactating women consuming the torbangun soup (Coleus amboinicus Lour). Media Gizi \& Keluarga, 29(1), 74-80.

Damanik R, Wahlqvist ML \& Watanapenpaiboon N. 2006. Lactagogue effects of torbangun, a bataknese traditional cuisine. Asia Pacific Journal of Clinical Nutrition, 15(2), 267-274.

Damayanthi E, Warsiki E, \& Damanik R. 2008. Penundaan Kerusakan oleh Antioksidan Vitamin dan Retensinya pada Sayur Torbangun (Coleus amboinicus Lour) Awet. Prosiding Seminar Nasional dan Kongres PAPTI (hlm. 1228-1237).

Santosa CM. 2001. Khasiat konsumsi daun bangunbangun (Coleus amboinicus L.) sebagai pelancar sekresi Air Susu Ibu menyusui dan pemicu pertumbuhan bayi. [Thesis]. Program Pasca Sarjana, IPB, Bogor.

Warsiki E, Damayanthi E, \& Damanik R. 2009. Karakterisasi mutu sop daun torbangun dalam kemasan kaleng dan perhitungan total migrasinya. Jurnal Teknologi Pertanian, 3, 28 $-33$ 